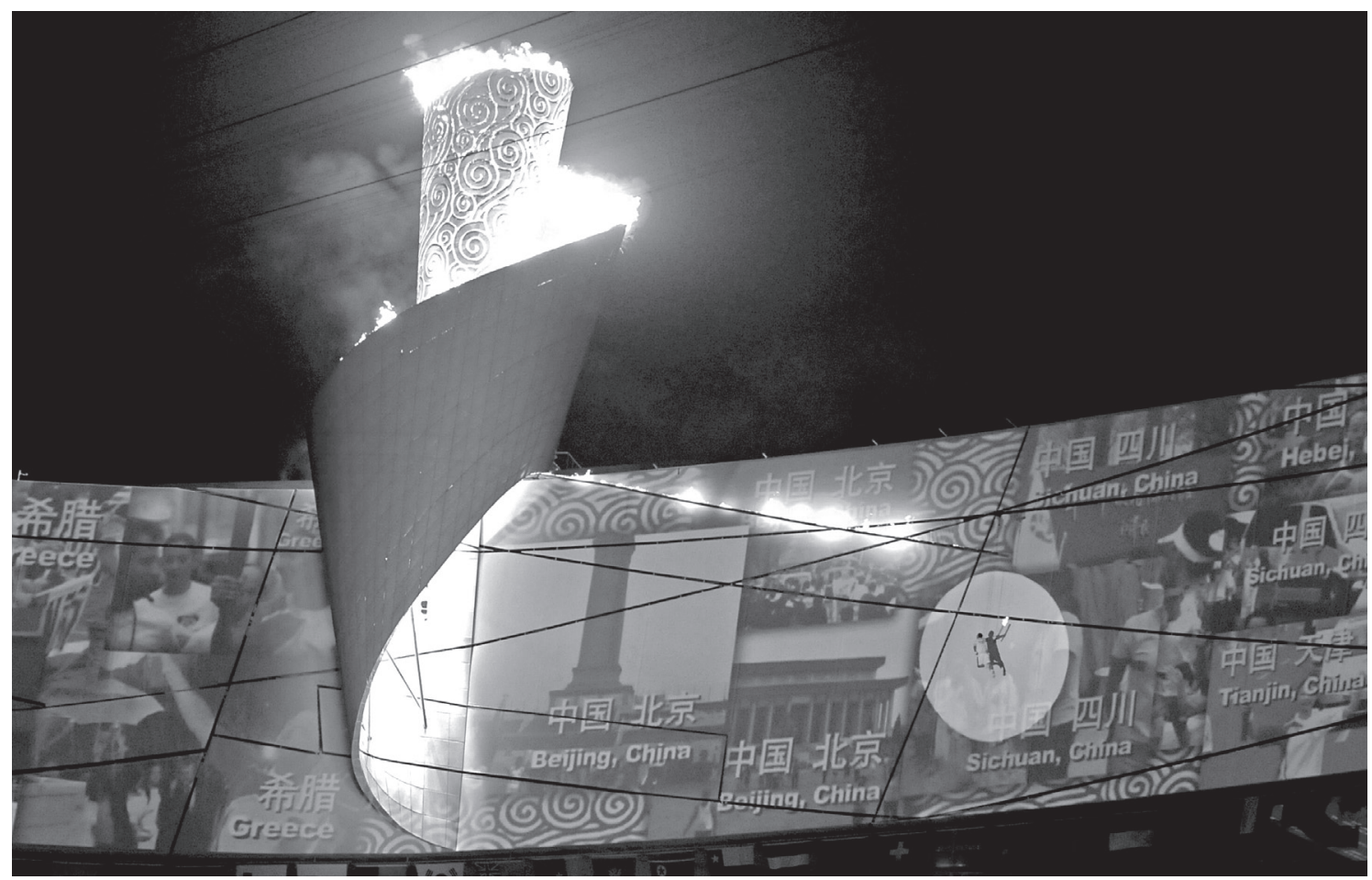

Den Olympiske fakkel for Beijing-Legene tæendes på det nationale stadion i Beijing i forbindelse med åbningsceremonien den 9. august 2008. Over 10.000 atleter fra næsten 200 lande skulle under Legene konkurrere i 38 forskellige discipliner (AFP PHOTO/DDP/MICHAEL KAPPELER, Scanpix, Danmark).

\title{
De politiske spil omkring OL i Beijing 2008 \\ - hvorfor blev de så dagsordensaettende, og hvilke virkninger fik de?
}




\section{INDLEDNING}

Hvad kom deltagelsen i OL - og den forudgående debat i Danmark og andetsteds - til at betyde for ønsket om at fremme menneskerettigheder i Kina? Spørgsmålet kan ikke besvares uden at sætte det ind $\mathrm{i}$ en analyse af den meget større ramme, som udgøres af de mange nationale og internationale politiske spil omkring OL 2008 i Beijing. ${ }^{1}$ Baggrunden er et Kina, som på den ene side fortsat er præget af mangfoldige menneskerettighedsproblemer, men på den anden side også gør fremskridt på området (Wang, 2008). I den situation valgte utallige ngo'er og bevægelser at bruge det sidste år før OL til at fremme egne sager og organisationer ved enten at skubbe dem ind i det projektørlys, som altid omgiver OL, eller at prøve at presse de kinesiske myndigheder ved at tage de kommende leges succes som gidsel. Mens ngo'erne ofte er idealistiske og folkeligt baserede, kan de også være udtryk for forskellige lande og myndigheders nationale in teresser og finansieret derefter. Staterne kan også selv være aktive. ${ }^{2}$

\section{TO CENTRALE SPØRGSMÅL}

Det dramatiske forløb rejser to vigtige problemstillinger: For det første, hvordan kunne de mange spredte aktører, især ngo'er, få så stor indflydelse på »dagsordenen«, som tilfældet blev? For det andet, hvilke formål lå bag de mange forskelligartede aktiviteter, og hvordan kan man forklare variationerne i opnåelsen af disse mål?

Mit svar på det første spørgsmål vil tage udgangspunkt i »framing «-begrebet og argumentere for, at nationale og internationale massemedier, som var centrale og uundværlige medspillere for de vekslende aktører, siden 1990'erne er præget af en negativ "framing " omkring Kina og derfor umiddelbart fungerede som "forstærker« for de mange sager og organisationer - frem for som kritisk instans. Det gik ud over præcision og troværdighed. Den dagsordensættende effekt styrkes af mediekoncentrationen, der betyder, at fem gigantiske mediekoncerner nu dominerer over halvdelen af USA's medieverden. Spørgsmålet analyseres gennem en diskussion af udviklingen i framing og nogle tilfælde (eller cases), der viser dens tilstedeværelse forud for OL, f.eks. i dagsordener knyttet til spørgsmålet om "løfter «, Tibetreportagen, fakkelstafetdækningen etc. Det er denne partiskhed via framing, der nu som noget nyt observeres af den kinesiske befolkning gennem »boundary spanners« (folk, der danner bro over grænser). Det, at partiskheden er blevet synlig, kan medvirke til at forklare den manglende eller ligefrem modsatrettede virkning af dele af det bombardement, ngo'erne udsatte Kina for.

Omkring den anden problemstilling er mit argument, at der var flere kategorier af formål fra idealistisk/religiøse over rent organisatoriske til politiske/storpolitiske. Den variable målopfyldelse hen over disse kategorier kan forklares ved at skelne mellem mål, der var interne $\mathrm{i}$ forhold til Kina, og mål, der var eksterne. De første blev hårdest ramt af forløbet igennem 2008, som nemlig kom til at styrke kinesisk nationalisme og udløste en xenofobisk reaktion, fordi den med hjælp fra regeringen og det store Wenchuan jordskælv i maj kom til at handle om suverænitet og »udenlandsk indblanding«. Men også den ovenfor omtalte mediebias og -troværdighed samt manglende anerkendelse af opnåede fremskridt og modsatrettede forventninger til OL spillede ind. Teoretisk trækker analysen på begreber om nationalisme og suverænitet i Kina samt om "gruppepolitik« og blød magt (Nye, 2004). Den inddeler aktørerne i tre kategorier og analyserer årsagerne til den skiftende målopfyldelse. Kilderne til analysen af begge pro- 
blemstillinger er dels massemedier og opinionsundersøgelser, dels personlige meddelelser fra aktører af forskellige typer.

Det kan være nyttigt indledningsvis at minde om nogle kontekstuelle faktorer i Kina i kalenderåret 2008 startende med januar og de værste snestorme i 100 år over Spielberg's Darfur-begrundede fratræden som kunstnerisk rådgiver $\mathrm{i}$ februar og en amerikansk Kongreshøring ${ }^{3}$ til Tibet-urolighederne, der begyndte 14. marts og fortsatte en tid. Helt siden 2001 havde eksiltibetanere skrevet om OL som den helt store mulighed for at presse Beijing. I maj indtraf det store Wenchuan-jordskælv, og samtidig var den olympiske fakkelstafet blevet politiseret og med start i Olympia ramt af omfattende demonstrationer i land efter land (for og imod). Begge forløb fortsatte i juni. I juli prægedes en del lande af diffuse boykotdiskussioner ${ }^{4}$ - også i Kina, nemlig på det folkelige plan mod den franske stormagasinkæde Carrefour - og netop i starten af august lancerede separatistiske uighurgrupper i Xinjiang-regionen terrorangreb. Under OL fortsatte især den anglo-amerikansk baserede Tibetkampagne med nogle små aktioner i Beijing. Mindre synligt har f.eks. menneskerettigheds-ngo'er og bevægelsen Falun Gong været aktive i skrift og tale gennem hele året.

\section{FRAMING-BEGREBET}

"The cardinal sin committed by American news organisations in covering China is to portray it, always, in one overly simplistic frame« (Mann, 2001, s.102). ${ }^{5}$

"Hvad mener jeg med en »frame«? Jeg mener, at historier $\mathrm{i}$ amerikanske medier har det med på ethvert givet tidspunkt at være styret af en enkelt historie, et enkelt image eller begreb. I 1950'erne og 1960'erne var

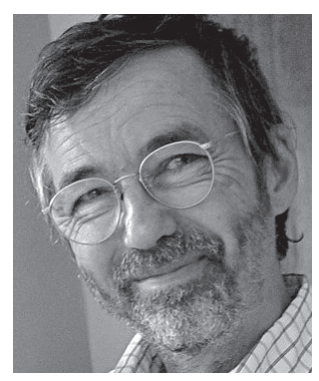

det Kina som små blå myrer eller robotter. I 1970'erne, efter Nixons åbning, var rammen de gode (underholdende, søde) kinesere, som viste deres tidløse kvaliteter selv under kommunisme. I 1980'erne var rammen "Kina er ved at blive kapitalistisk«. Og i 1990'erne blev rammen så det repressive Kina.« (Ibid).

Den er ikke ændret meget med hensyn til det repressive, men måske udvidet med temaet »den kommende supermagt (og dermed rival) Kina«.

Rammen styrer, siger Mann, tænkemåden hos redaktørerne derhjemme, til hvem korrespondenterne rapporterer, så der skal altid noget med om rammen, hvis man vil have sin artikel på. Den danner baggrunden, den antagne kontekst, og fordi den nu går på det repressive regime, så skal hver eneste historie om Kina handle om eller runde temaet politisk undertrykkelse. I 1980'erne var det anderledes (Østergaard, 1990). Dengang "tjente det Amerikas kold-krigs interesser at gå let hen over de mørkere sider af Kinas adfærd. Kina var den strategiske allierede mod Sovjet, og billedet i de amerikanske medier understøttede dette.« (Mann, 2001, s.104).

"Producere, redaktører og nyhedsjournalister må holde op med at reducere Kina til en enkel fortælling ... og først og fremmest så må amerikansk mediedækning af Kina udfordre de eksisterende antagelser og være forberedt på det uventede.« (Ibid). 
Dette er den erfarne praktikers konklusioner Men »frame«-begrebet er en anerkendt videnskabelig term. Medierammen er sa central organizing idea or story line that provides meaning to an unfolding strip of events ... The frame suggests ... the essence of the issue." (Gamson \& Modigliani, 1987). Rammerne er "for det meste uudtalte og uerkendte, og de organiserer verden ... for de journalister, der rapporterer om den“ (Gitlin, 1980). R. M. Entman kom i 1993 med en mere præcis definition: "At »frame« er at udvælge nogle aspekter af en opfattet virkelighed og gøre dem mere centrale i en kommunikerende tekst, på en sådan måde at de promoverer en særlig problem-definition, kausal fortolkning, moralsk evaluering, og/eller behandlingsforslag.» (Entman, 1993, s. 52). Den påvirker dermed ganske stærkt også modtagernes forståelse af begivenhederne, og begivenheder er der jo næsten altid tale om i medierne, frem for analyser af længere "tendenser", (Lampton, 2001, s. 264).

Journalistikkens »framing « af en begivenhed påvirkes af samfundsstrukturer og organisatoriske forhold såvel som af ideologiske og individuelle variabler. Scheufele (1999) ser »mindst fem faktorer, der potentielt indvirker på, hvordan journalister framer et givent sagområde: sam-

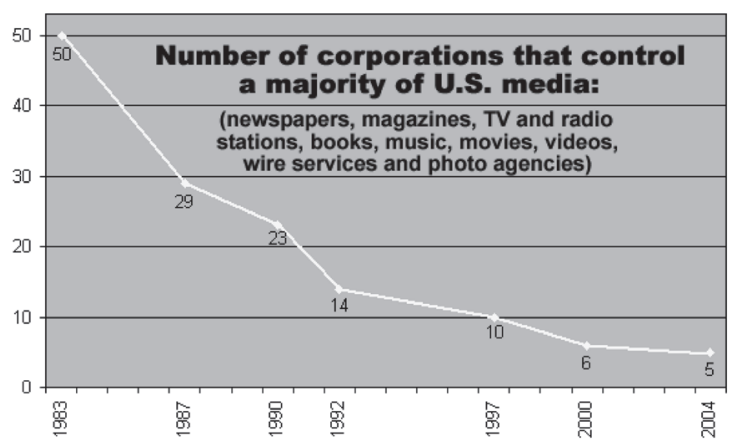

fundsnormer og værdier, organisatoriske pres og begrænsninger, interessegruppers pression, journalistiske rutiner og journalisternes ideologiske eller politiske orientering." (s. 109). Argumentet strammes yderligere af Edelman (1977), der siger: "myndigheder og pressionsgrupper kategoriserer forestillinger på en måde, der fremkalder støtte eller opposition til deres synspunkter," og de bruger massemedierne til at konstruere meninger og virkelighed og fastlægge visse referencerammer« (s. 51). ${ }^{6}$ Dette synspunkt holder for så vidt stik for amerikansk Kina-dækning, om hvilken Chang (1993) i en større undersøgelse over tid fandt, at den altid var på linje med regeringens skiftende politik over for Kina.

Denne forskning giver ikke noget svar på, hvorfor rammen fortsat er "repression « trods de omfattende forandringer over den snes år, der er gået siden Tiananmen i 1989 - og trods de mange autoritære systemer, hvorpå denne ramme ikke finder anvendelse (French, H., 2008). Nogle mulige forklaringer på eliteinteresse $\mathrm{i}$ at fastholde denne ramme kunne være: 1 . opfattelsen af Kina siden ca. 1995 som en strategisk og økonomisk konkurrent, 2. en opfattet "modelkonkurrence«, hvor man må arbejde på at reducere anseelsen og dermed tiltrækningskraften for en model, der fastholder en betydelig rolle for staten under kapitalisme, og - forbundet hermed - 3. mediernes egen interesse $i$ at overvinde de barrierer, som etpartistaten fortsat opretholder over for de 5-10 gigantiske mediekoncerners uhindrede kontakt til den store markedsgruppe på 2-300 mio. mennesker, som Kinas middelklasse udgør. Alle har de filmselskaber og satellitter, der gerne vil sende reklamer ned til hundreder af millioner af paraboler i Kina eller lave kabel-tv. 4. Endelig er der vedholdende, både i medierne og den øvrige elite, en forestil- 
ling om, at "regimeudskiftning « i Kina ville tilgodese alle de ovenfor nævnte bekymringer (og være vildt populært i Kina). Den nylige Nobelpris-vinder i økonomi, professor og klummeskriver på New York Times Paul Krugman, formulerede det meget skarpt i 2007 i et interview med Rory O'Connor: "The media's bias, a large part of it is in fact right-wing bias, because they are effectively part of the right wing" (O’Connor, 2008).

I det amerikanske mediebillede, som afgørende præger (og delvis ejer) den øvrige vestlige verdens nyhedsorganisationer, og da især Danmarks, er der oven i købet sket en stor forandring de seneste tiår. Fra et antal på 50 i 1983 er man nået ned til under 10 store fusionerede mediekoncerner, hvoraf blot fem, "The five big sisters«, dominerer over halvdelen af de samlede medier af enhver slags i USA, men også i Europa er medieverdenen stærkt koncentreret (se fig. 1). Skarp indbyrdes konkurrence giver en tendens til sensationalisme, overfladiskhed og "nyhedsunderholdning " (infotainment) i kapløbet om seertal. Det drejer sig om General Electric (NBC), AOL-Time Warner (CNN), Viacom (CBS), Robert Murdoch's News Corp (Fox TV) og Disney (ABC). Det giver dels mindre alsidighed og åben debat, dels øget indflydelse til nogle få personer og interesser. Undertiden griber disse direkte ind i det redaktionelle arbejde, men oftest fungerer der en selvcensur (Pew, 2000). De få bestyrelsesmedlemmer og administrerende direktører sidder samtidig i bestyrelser i andre store koncerner, og forbløffende mange er bankfolk, dvs. fra en anden sektor, der gerne vil til fadet i Kina.

Denne drøftelse af rammer og mediekoncentration støtter mit argument om, at de mange spredte aktører, især ngo'er, derfor havde let ved at få mediernes samarbejde. Disse blev til mikrofonholdere og megafoner for »enkeltsags«organisationerne, og de undlod mestendels at stille kritiske spørgsmål. Nogle eksempler (cases) fra det seneste år kan illustrere det.

\section{ANALYSE AF FIRE TILFALDE AF SAMSPILLET} MELLEM NGO'ER OG MEDIE-»FRAMING«

Det var ngo'er som Amnesty og Human Rights Watch-Asia, der et år før OL lancerede slagordet om, at Kina ikke havde overholdt de løfter om forbedring af menneskerettighedssituationen, som det afgav i forbindelse med opnåelsen af værtskabet. I løbet af året antog denne påstand et selvstændigt liv i de globale medier i den form, at Kina simpelthen på upålidelig vis havde brudt sine løfter og ikke opfyldt IOC's betingelser for afholdelse af OL. Et år senere talte Amnesty stadig om »de svulmende løfter «, Kina afgav (Amnesty International, 2006 \& 2008). På det tidspunkt havde IOC selv allerede uden held forsøgt at korrigere denne opfattelse: "Det er en løgn ... Det eneste, IOC bad Beijing om i opløbet til ræset om OL 2008, var at tillade den internationale presse at rapportere frit om legene. De holdt det løfte fuldstændigt. Hvis Amnesty siger: vi synes, de fremskridt Kina har gjort, er utilstrækkelige, så har de ret til det. Men de bør ikke skabe det forkerte indtryk og bruge legene til at gøre det. Hvert løfte Kina har givet os er blevet overholdt « (Volkskrant, 2008). Flere medlemmer af Beijing bys ansøgningskomite gav dog i interviews udtryk for, at Kinas afholdelse af legene, blandt meget andet, da også ville gavne udviklingen af menneskerettigheder (»will also benefit the further development of our human rights cause «). Det forekommer også sandsynligt, at det på længere sigt vil være tilfældet, på trods af de forudsigelige stramninger i månederne op til legene.

En idrætsforsker, Susan Brownell, sagde da- 


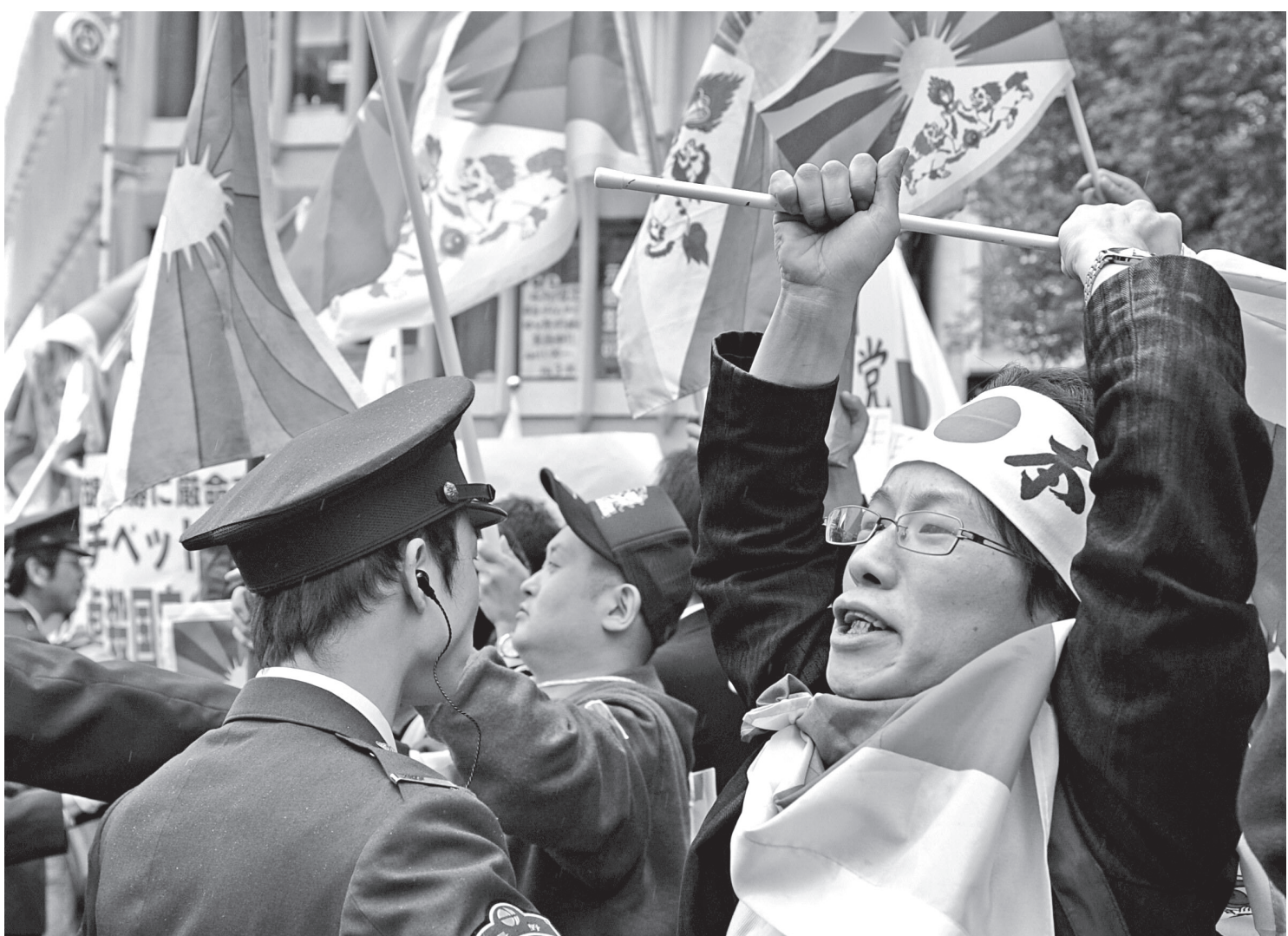

Ordensmagten kontrollerer pro-tibetanske demonstranter i forbindelse med den olympiske fakkelstafet gennem Nagano den 26.april 2008. Ifølge vidner endte denne japanske del af fakkelstafetten i et fire timers voldsomt slagsmål, hvor fire mennesker kom til skade (AFP PHOTO/Kazuhiro NOGI, Scanpix, Danmark).

gen før OL: »I think really there was an attempt to avoid promising anything, rather than an attempt to make promises. That human right groups have been saying China made promises, I think that's wishful thinking. I understand why they're doing that - it's a political strategy. But I am a social scientist, and from that perspective, that's just not true" (Badger, 2008). Som man kan se af referencerne, er det små ukendte me- dier, der bringer disse berigtigelser; de store fortsætter blot linjen, sådan som man ville forvente ud fra den fremherskende "framing «.

Det område, hvor der faktisk blev afgivet et løfte, var regler omkring udenlandske journalister. I december 2006 udstedte Statsrådet et midlertidigt regelsæt, som forbedrede arbejdsvilkårene for de forventede 20-30.000 udenlandske journalister indtil legenes afslutning. De 
blev i oktober gjort permanente og er således et af de blivende resultater af OL's afholdelse (Regulations, 2008).

\section{TIBET-SPøRGSMÅLET}

Et andet felt, eller en anden case, hvor den kinesiske befolkning kunne se en skævhed eller en bias i vestlige medier og ngo'ers virke, var Tibet. ${ }^{7}$ Dækningen af de voldelige demonstrationer i Lhasa, som begyndte d. 14. marts, rummer en del problemer, som kan henføres til "framing«. For det første nedspillede medierne de dødelige angreb på utallige ikke-tibetanske kinesere og afbrændingen og plyndringen af næsten alle ikke-tibetanske forretninger såvel som af uighurernes moske i Lhasa (Kyodo, 2008). For det andet overtog man ukritisk udokumenterede tibetanske tabstal fra eksilorganisationer i Indien, en notorisk upålidelig kilde, som normalt ville kræve uafhængig bekræftelse. ${ }^{8}$ For det tredje ignorerede man omhyggeligt, at der faktisk havde været en af verdens mest kvalificerede Kina-reportere, James Miles fra "The Economist«, på pletten i Lhasa i den pågældende uge, og at han oven i købet havde færdedes frit. Han blev berømt på sin dækning af Tiananmen-begivenhederne for $\mathrm{BBC}$, men problemet denne gang var muligvis, at hans øjenvidneberetning fra Lhasa underbyggede det, som kineserne hævdede, var sket (CNN, 2008).

For det fjerde var det billede, kineserne fremstillede, og som Miles altså bakkede op om, en politiaktion, som ikke lå fjernt fra det, vi så i Los Angeles 1992, i Paris 2005 eller sågar på Nørrebro i København. Men det var ikke stærkt nok til medieframen, så derfor blev billeder beskåret kreativt, gamle film hentet frem, eller man brugte - også i DR2 Deadline - simpelthen billeder af brutale politifolk, der tævede løs på munke $i \mathrm{Ne}$ pal - uden at oplyse seerne om lokaliteten. Som en dansk sinolog og Tibetkender skrev, så blev al anstændighed smidt over bord, især i TV-dækningen (Clausen, 2008). Kinas public relationsstrategi var også elendig, må det siges. Endelig, for det femte, var der intet journalistisk forsøg på at udrede de komplicerede tråde imellem det, der skete i Lhasa og eksiltibetanernetværket, hvis vigtigste hovedkvarter ligger i Washington, og ikke hos Dalai Lama i Dharamsala, og hvis vigtigste finansiering stammer fra USA's National Endowment for Democracy (NED), der som bekendt også finansierede de såkaldte "kulørte revolutioner « $\mathrm{i}$ en del lande mellem Europa og Tibet (French, P., 2008). Det er tankevækkende, at to førende medier, New York Times og Wall Street Journal, i de fire forudgående år ikke havde haft en eneste artikel om Kinas håndtering af Tibet-problematikken.

Disse fem punkter var med til at give den kinesiske befolkning et indtryk af en vestlig medie-dækning, som var unfair, forudindtaget og måske, i sidste ende, sigtede på at dele Kina op. Dermed berørte man det af historiske grunde ømfindtlige suverænitetsspørgsmål, en rød streg, som når den krydses, får befolkningen til at samle sig om og støtte parti og regering.

\section{FAKIKELFORLØBET OG DE TO BEDSTEMØDRE}

En tredje case, eller en tredje medvirkende faktor, var det meget ydmygende forløb omkring den olympiske fakkel. Allerede da den skulle tændes i Olympia, var der som bekendt fysiske overgreb fra demonstranter fra den Paris-baserede organisation Reporters without Borders samt "Free Tibet«-bannere; det fortsatte i Paris, hvor især overfaldet på den kørestolsbundne kinesiske fægtepige fik ikonagtig betydning i Kina, og i London og San Francisco var der ligeledes tumulter (Fan, 2008). Når medierne rapporterede, var dem, der angreb faklen, helte i en 
retfærdig sag, mens de stadig voksende moddemonstrationer af indignerede oversøiske kinesere blev opfattet, som var de blot udkommanderede af ambassaden (Edney, 2008). ${ }^{9}$

En fjerde mere bagatelagtig case tager jeg med, fordi den er repræsentativ og blev brugt til at vise, at Beijing tværtimod "løfterne« havde strammet på menneskerettighedsområdet. To bedstemødre og tidligere naboer, Wu Dianyuan og Wang Xiuying, ville gerne demonstrere under OL over, at de havde fået for lav kompensation, da deres huse i 2001 blev eksproprierede. ${ }^{10}$ Det kan være helt rationelt at klage; der er eksempler på, at kompensationen for ekspropriering er blevet forhøjet fra f.eks. 250.000 til 700.000 yuan. De søgte om demonstrationstilladelse fem gange, men til sidst, den 17 . august, besluttede myndighederne at anholde dem for at "forstyrre den offentlige orden «. Det skete administrativt under »Reform gennem arbejde«-lovgivningen (som med rette kritiseres af MR-ngo'er), men i dette tilfælde ikke i form af arbejdslejrophold, blot med begrænsning på deres bevægelsesfrihed. Nyheden om »bedstemødre et år i arbejdslejr « gik verden rundt, stærkt støttet af ngo'en HRIC i Washington. Hvad der ikke fik så meget opmærksomhed var, at forstyrrelsen af den of fentlige orden bestod $i$, at de to havde anbragt 30-40 stykker fyrværkeri i et metalrør og, efter et første mislykket forsøg bragt det til sprængning uden for partiets hovedkvarter i Zhongnanhai midt i Beijing. ${ }^{11}$

Disse fire tilfælde underbygger min påstand om, at medierne i almindelighed temmelig ukritisk viderebragte ngo'ers og interessegruppers fremstillinger af vigtige sagsforhold. ${ }^{12}$ Rigtig problematisk bliver dette dog først, når det når frem til den kinesiske befolkning. Det har vi været vant til, at det ikke gjorde, eller i hvert fald kun gjorde i en form, hvor befolkningen måtte regne med, at de nok var udsat for monopolagtig mediestyring fra regeringens side og derfor diskonterede informationerne. Det nye er, at der er mere transparens set fra Kina-siden. Det skyldes, at der opstået en ny kategori af »boundary spanners« (Carlson, 2007, s. 254). Den kinesiske diaspora på ca. 35 mio. mennesker er i meget tættere kontakt med hjemlandet end tidligere, de over 350 mio. kinesiske "netizens«(net-indbyggere) er godt integrerede i internettet, ${ }^{13}$ der er foruden turister på ethvert givet tidspunkt hundredetusinder af kinesiske studerende i Vesten, og der er et stigende antal kinesiske deltagere i transnationale bevægelser af forskellig art, f.eks. Greenpeace og World Wildlife Fund. De giver inputs, som skaber øget transparens, fordi de kan følge de internationale agendaer, medieadfærden, "framing«-fænomenet mv., og videreformidle dem til kinesere i hjemlandet. Dvs. at bias, skævhed, asymmetri eller direkte billedfusk meget hurtigt bliver meget tydeligt. Også Vestens manglende anerkendelse af de fremskridt, der sker, herunder på menneskerettighedsområdet, bliver tydeliggjort og svækker troværdigheden af udenlandsk kritik. ${ }^{14}$

Sinologen Pei Minxin fra tænketanken er Kina-kritiker, men gav i en statusartikel efter OL karakteren »C-minus « for den vestlige dækning: "Western reporters and columnists dwelled excessively on hot-button (øm tå) issues, such as human rights and press freedoms, and offered a lot of blather about a clash between two systems. So very Cold War." »The Games strengthened the party's rule, leaving it under less pressure to reform" (Pei, 2008). Der var en enkelt britisk journalist, der advarede om dette allerede i april under angrebene på faklen: "Such demonstrations enhance rather than diminish support for a government rallying to defend itself against what it depicts as an affront to Chi- 
na's pride and dignity. The same goes for any boycot of the Games." (McGregor, 2008).

\section{HVILKEN EFFEKT HAVDE DE POLITISKE SPIL FØR OL} OG DE MANGE FORS $\varnothing$ G PÅ POLITISERING AF OL?

Den anden problemstilling lød: hvad var formålene med de mange forsøg på at bruge legenes "projektørlys«, og i hvilket omfang blev de opnået? Formålene med politiseringen af OL 2008 varierede over et bredt spektrum, og det kan tilmed undertiden være svært at vurdere om de erklærede mål også er de egentlige mål. Dertil kommer, at samme organisation jo kan have flere typer mål.

Der var for det første de rent idealistiske, f. eks. omkring forbedring af menneskerettighedssituationens forskellige dimensioner (fra organisationer som Amnesty International, Human Rights Watch-Asia, Human Rights in China, Chinese Human Rights Defenders, COHRE, Reporters without Borders, etc.) og de religiøse, f.eks. Falun Gong og organisationer fra USA's »Christian Right « som Family Research Council. AI opfordrede direkte atleterne til at bruge OLplatformen til at kritisere Kina (Kelso, 2008). I Kina var der også aktivitet, f.eks. startede en gruppe sagførere i januar en underskriftsindsamling (14.000 fik de) på et skrift, der opfordrede regeringen til at bede parlamentet ratificere også den anden af de to menneskerettighedstraktater, som Kina underskrev i 1998, og som dækker ytringsfrihed, religionsfrihed, forsamlingsfrihed m.m. (Buckley, 2008). Tilsvarende fremsatte en gruppe på 31 intellektuelle en tolvpunkts erklæring med kritiske forslag til regeringen omkring Tibetproblematikken (Twelve, 2008). ${ }^{15}$

For det andet er der de organisatoriske eller institutionelle målsætninger. En del ngo'er med "globale« mål ser også til daglig Kina som et godt grundlag for medlemskampagner og fundraising. Det gælder generelt, men OL-året gav et særligt fokus, og undersøger man f.eks. Amnestys kommunikationsstrategi over for eksisterende medlemmer, vil man se, at der blev lagt vægt på ekstra bidrag (Amnesty International, 2008). Samtidig lægges den normalt nøgterne rapportering om Kina til side, og lidt mere overskriftsfangende (men også dårligere dokumenterede) skrifter udsendtes. Da de må forventes at have mindre virkning $\underline{i}$ Kina end den årlige rapport, må formålet skønnes at have været organisatorisk: Medlemmer, aktivister og midler - i sidste ende organisatorisk vedvarenhed og overlevelse. Internationalt har de amerikanske fagforeninger AFL-CIO ofte vist deres eksistensberettigelse over for medlemmerne ved at bruge menneskerettighedskritik til at søge at stoppe importkonkurrencen fra Kina (Lampton, 2001, s. 126).

Til de organisatoriske mål hører måske også brugen af OL-kritik og boykotdiskussion til indenrigspolitisk positionering. I Danmark valgte De Konservatives hovedbestyrelse at bruge spørgsmålet om boykot til at markere selvstændighed i forhold til regeringspartneren Venstre. Tilsvarende holdt politikere fra to andre sfolkepartier«, Pernille Frahm (SF) og Søren Espersen (DF) (Jyllands-Posten 13.4), en høj kritisk OLprofil uden nogen særlig indsigt i problematikken, men formentlig med deres partiers accept. Simon Emil Ammitzbøls (tidligere R) boykotudspil vakte til gengæld opsigt hos De Radikale. En underkategori kunne måske være enkeltpersoners selvpromovering med OL-kritik og boykot brugt som »køretøj«, en form for enmandsorganisation på opportunistisk grundlag, som også findes uden for det partipolitiske liv. På internationalt plan var der i øvrigt en tendens til at politikere med lave ratings, f.eks. Sarkozy i Frankrig, borgmesteren i Paris og Hilary Clinton 
i sin kampagne, fór ud med stærke reaktioner i forår og sommer, måske i håb om en populistisk gevinst. I Tyskland engagerede både Bundestag og Ewangelisches Missionswerk sig i menneskerettigheder og OL. Til gengæld manglede der ganske politikere, der var modige nok til at gå ud og forklare, at det er en dårlig idé at overlade Kinapolitikken til medierne og gadens parlament, og at forbindelserne til en kommende supermagt ikke kan varetages på den måde, men kræver vision og langsigtet tænkning.

En tredje kategori af mål er de politiske, herunder også storpolitiske. Eksemplerne er mange, fra Mia Farrow's New Yorkbaserede "Save Darfur«-kampagne over Burmarelateret pres til separatiske uighurer i og uden for Xinjiang, og tibetanere i og uden for Tibet. Også de neokonservatives tænketanke i USA var aktive med sammenligninger med OL i 1936 (Tkacik, 2008). Disse mange mere eller mindre løse organiseringer forsøgte at bruge Kinas håb om et vellykket, ikke-politiseret OL til at presse politiske mål igennem. Hvor de første to overvurderede Kinas indflydelse og undervurderede dets allerede lagte pres (Østergaard, 2008), gjaldt det for de sidste to, at de overvurderede OL's betydning og undervurderede Beijings resoluthed. ${ }^{16}$ Til de politiske mål hører også dem, der fremføres af kinesiske dissidenter i især USA, men også af f.eks. Ren Wanding på sin rundrejse i Europa. ${ }^{17}$

På det storpolitiske plan, og repræsenteret af andre stormagter og nationer, var der modstridende mål, ofte helt ned i den enkelte regerings forskellige organer. På den ene side et erklæret sigte om at integrere og indbinde Kina mest muligt $\mathrm{i}$ alle internationale sammenhænge for derved at stabilisere det internationale system og dets organisationer og regimer samt om at opnå samarbejde med Kina om ellers uløselige globale problemer. OL i Beijing var et led heri. På den anden side en stigende bekymring, vel især hos USA, over Kinas voksende »bløde magt« og vellykkede globale diplomati (Nye, 2004). OL var også et led i disse fremskridt (Cull, 2008). Det kan naturligvis ikke blive en erklæret politik at prøve at reducere Kinas »blød magt«-gevinster ved et vellykket OL, men det er næppe utænkeligt, at det for nogle dele af det amerikanske politiske system har været et delmål (Garrison, 2005). Herunder de kredse, der ser det som en vigtig opgave at fastholde indtrykket af en "Kinatrussel» (Deng, 2008). Der flyder ganske store midler rundt til sådanne formål, bl.a. på grund af Kongressens særlige bevågenhed og Pentagons fokus på information og misinformation under Rumsfelds ledelse, og det er påfaldende, at virkelig mange af de organisationer eller personer, der var mest aktive i året op til OL, har modtaget støtte fra især National Endowment for Democracy, som er en kanal for amerikanske regeringsmidler. Kongressen samarbejder også tæt med ngo'er som HRIC, HRWAsia og Reporters without Borders (jfr. høringen i note 3). Hvor effektivt mediekoncerner kan spændes for vognen, så man f.eks. ved Irak-krigens start og senest ved det gennemførte spin omkring Georgiens angreb på Syd-Ossetien. I begge tilfælde kom de mest ansvarsbevidste medier med beklagelser, men først længe efter.

\section{NATIONALISME OG SUVERAENITET?}

Når man skal opstille forventninger til variationen i målopfyldelsesgrad hen over disse kategorier, ligger der efter min mening et fingerpeg $\mathrm{i}$ det omfang, de vekslende formål eller krav berører nationalisme eller suverænitet. Sinologen David Shambaugh taler om to kinesiske nationalismer, en forurettet, defensiv nationalisme og en selvtillidsfuld og stolt nationalisme, og siger:

"Kinas samfund rummer begge typer, og det 
afspejler et dybere dualistisk sæt af identiteter: en xenofobisk type med rødder i de ydmygelser, den kinesiske befolkning undergik, og en mere kosmopolitisk version, som formes af globaliseringen og Kinas integration i det internationale samfund" (Shambaugh, 2008).

Den første har dybe rødder i den uværdige behandling, Kina blev udsat for af europæiske kolonimagter, amerikanske missionærer og japanske besættelsestropper i det, som kinesiske skolebøger kalder »et århundredes skam og ydmygelse«. Den nuværende kinesiske stats adkomst til magten, og yndede propagandatemaer siden, var at forene nationen, genetablere dens værdighed og aldrig igen lade landet underkaste eller opdele af udlændinge. Som Shambaugh skriver, er det »derfor spørgsmål som Tibet, Taiwan og Xinjiang i den grad rammer en nerve i Kinas samfund. En del af Kinas psyke har en meget lav tærskel for udenlandsk kritik, (og) nul tolerance for »tab af ansigt«...« (Ibid). Den anden nationalisme er stolt af Kinas nyfundne rolle i verden, dets status som stormagt, dets rolle som globalt økonomisk lokomotiv (det bidrog med $27 \%$ af verdens vækst i det seneste år), dets socioøkonomiske forvandling og dets bidrag til international problemløsning. Det var det image, som OL skulle fejre. ${ }^{18}$

Man kan også lave en anden sondring. Kinesisk nationalisme drives fra to kanter, dels en statsanført top-down og dels en »bottom-up« eller folkeligt drevet nationalisme anført af liberale nationalister. De er egentlig tilhængere af reformer af det kinesiske system, men siden 1990'erne er de i stigende grad blevet skeptiske over for Vestens intentioner. Begivenhederne omkring OL-året kom til at skærpe denne skepsis betydeligt, til dels som følge af den mis-re- præsentation som er vist ovenfor, til dels fordi støtten til Tibet og Xinjiang berører den ømfindtlige suverænitetsproblematik, og endelig fordi meget af den udenlandske kritik sås som ubeføjet og præget af uvidenhed. Som en erfaren iagttager af Kinas nationalisme, Suisheng Zhao, siger, skete der det, at "Kinas ungdom (og højtuddannede), engang de centrale aktører i 1989-demonstrationerne, nu fører an i kampagnen om at slutte op om regeringen. De kinesiske unge har sønderlemmende kritiseret Vesten med beskyldninger om, at den ikke forstår Kina og ønsker at forhindre landet $\mathrm{i}$ at blive en stormagt." (Zhao, 2008, s. 48).

Forløbet igennem 2008 gav en xenofobisk reaktion, fordi det - med hjælp fra regering og naturkatastrofer, men altså også fra udlandet kom til at handle om suverænitet, mediebias, modsatrettede forventninger og udenlandsk indblanden. ${ }^{19}$ Reaktionen må forventes at ramme forskelligt på de tre kategorier af mål - idealistisk/religiøse, organisatoriske og politiske - og få forskellig virkning på de mål, der er henholdsvis interne og eksterne $\mathrm{i}$ forhold til Kina. Jordskælvet og håndteringen af det fik f.eks. en stærkt samlende virkning på civilsamfund og stat, som umiddelbart svækkede mål i første kategori, mens omverdenens udviste sympati fik en mildnende virkning på xenofobien, sådan at integrationsmålet i tredje kategori på længere sigt led mindre skade (Ford 2008).

\section{ANALYSE AF MÅLOPFYLDELSEN OVER TRE KATEGORIER AF FORMÅL}

De idealistiske og religiøse organisationer kunne ikke pege på nogen positive resultater af kampagnerne op til OL. Tværtimod er det almindelig antaget, at etpartistaten blev styrket af hele forløbet, og krav om menneskerettigheder og politiske reformer blev svækket i takt med 
opbakningen om partiet. ${ }^{20}$ Derimod finder en sinolog som Cheng Li på Brookings Institution, at der på langt sigt vil være en menneskerettighedsog mediefrihedseffekt af selve legenes succesfulde afvikling, og det fordi det har styrket den liberale fløj af regeringen: " Jeg tror, OL vil gøre Kina mere åbent, mere transparent, mere tolerant og mere selvtillidsfuldt... den liberale fløj vil argumentere for, at der ikke er grund til at være bange for internationale medier, international integration, og også til en vis grad åbenhed og transparens. (...) Måske vil det tage 5-10 år til, men det er helt klart, hvem der vinder slaget " (Einhorn \& Delevingne, 2008). Vi må samtidig erkende, at vores målemetoder er utilstrækkelige og kausalsammenhængen ofte uklar.

Når kampagnen udefra derimod vakte modstand, skyldes det øjensynligt en kombination af forskellige faktorer. Et element var den manglende erkendelse eller kreditering af Kinas fremskridt. Fakkeldemonstrationerne blev særlig ydmygende på grund af modsatrettede forventninger: for kineserne stod OL som en lejlighed til at vise, at man er blevet et moderne land og ønsker engagement med Vesten, for vestlige medier blev det "et udstillingsskab for voldelig aggression, censur og politisk forfølgelse fra et regime, som ikke har klaret at hæve sig over politistatens niveau « (Zhao, 2008, s. 53). Kun en enkelt meget erfaren kinesisk-kyndig journalist gik i mod strømmen og skrev om den overordnede tendens med overskriften "Trods mangler, er rettighederne i Kina udvidet « (French, H., 2008), og her kunne kinesere genkende deres virkelighed. Opfattelsen af en generel mediebias formidlet via »boundary spanners" og formuleret $\mathrm{i}$ blogs og chatrooms udløste en xenofobisk reaktion: udlandet forstår os ikke. Forbavselsen var desto større, fordi befolkningen, på baggrund af de store forbedringer, de selv oplever, mener, at udlandet nok må se positivt på udviklingen i Kina. Et andet element drejede sig om suverænitet, faren for landets opsplitning og historiens ydmygelser. Det var Tibet-begivenhederne og den skæve dækning af dem, der ramte denne nerve. Med en kinesisk kollega, professor i International Politik, Shi Yinhongs, ord: "Vestens respons på Tibet genantændte fornemmelsen af, at selvom vi er rigere og mere liberale, så vil de stadig behandle os, som om vi var i 1800-tallet « ${ }^{21} .^{22}$ Så selve det forhold, at ngo'erne gik løs på Kina fra udlandet, var med til at modarbejde deres gode hensigter. Dels fordi det vakte de historiske erindringer, dels fordi Vesten ikke længere kan trække på den samme goodwill som f.eks. i 1980'erne. Med omverdenens sanktioner og Clintons angreb på Kina i 1993-4 startede nemlig en mistanke om, at det $\mathrm{i}$ virkeligheden er et geopolitisk behov, nemlig for at stække en stadig stærkere rival, der ligger bag fremføringen - fra især amerikansk side - af krav om menneskerettigheder og demokrati. Bush-periodens hykleri og dobbeltstandarder på disse felter syntes at bekræfte denne antagelse. Også diasporaen følte, at OL dels måtte stå over politik, dels var en historisk rehabilitering: "No matter whether you support or oppose the Beijing government, we see the Olympics as an achievement for all the Chinese people everywhere" og "Our joy is not for Communists, it's for what hosting the Olympics means to the history of the Chinese people« (Eckholm, 2008).

Hvad angår de organisatoriske og institutionelle mål, er det endnu lidt tidligt at konkludere. En klar indikator er medlemstal og indtægter. For Amnesty i Danmark var det henholdsvis 86.903 og 61 mio. kr. ved udgangen af 2007 (Årsberetning, 2007), men de tilsvarende tal foreligger endnu ikke for 2008. Den indenrigspolitiske anvendelse, $\mathrm{i}$ form af boykotudspil, partipolitik 
eller selvpromovering, forekom relativt mislykket. Dels fastholdt statsministeren sin klare linje, mens Brian Mikkelsen og De Konservative måtte bakke ned fra en boykot af åbningsceremonien, dels fik den store opbakning - over dobbelt så mange statsoverhoveder som i Sydney, herunder Kronprins Frederik - og det vellykkede forløb af legene disse aktører til at tage sig dårligere ud i tilbageblikket. For Sarkozy blev det ligefrem nødvendigt at sende mindst tre topfolk til Beijing for at undskylde.

Den tredje kategori er de politiske og storpolitiske mål. For de vekslende grupper med politiske mål er selve det at få omtale jo en politisk gevinst. Men ser man på de resultater, der kan konstateres på nuværende tidspunkt, er billedet mindre lyst. Kina har siden 2006 været inde i et effektivt diplomatisk samarbejde med andre stormagter om at presse Sudan, og virkninger af den New York-baserede Darfurkampagne er svære at spore (Østergaard, 2008). Værre gik det for to andre »sager«, nemlig Øst-Turkestans uafhængighedsbevægelse (ETIM), som figurerer på den internationale terroristliste, og de forskellige ngo'er og eksilorganisationer, som er aktive omkring Tibet. ETIM's bombesprængninger og snigmord i Xinjiang umiddelbart før OL har ført til en meget stram politik over for de 8 mio. uighurer, som udgør et mindretal af regionens befolkning, og formentlig reduceret deres religionsfrihed, f.eks. ved lukning af koranskoler. For Tibets vedkommende lod Beijing sig tilsyneladende presse til at intensivere det nyeste forhandlingsforløb, som har kørt i seks år, alt imens man dog strammede politisk i regionen og øgede antallet af styrker. Men de fornyede forhandlinger brød endeligt sammen ved tredje runde i oktober, og på et stærkt publiceret pressemøde den 10. november beskyldtes tibetanerne bittert for at have søgt at boykotte og ødelægge OL, inddrage udlændinge i deres forsøg på at lægge pres på centralregeringen og lave en forenet front med »oversøiske demokratiaktivister, Falun Gong elementer og Øst-Turkestan terrorister " for at opdele Kina (Dasgupta, 2008). Eksiltibetanerne er splittede på den fremtidige strategi, men observatører siger, at International Campaign for Tibet (ICT) baseret i Washington er stærkere og mere velfinansieret end Dalai Lamas eksilregering i Nordindien, og at "halen vil kunne logre med hunden " (French, P., 2008).

De storpolitiske mål var dobbelte. Sigtet omkring integrering og indbinding kunne have opnået bedre målopfyldelse. OL er jo et af de meget konkrete udtryk for integration af Kina og en oplagt måde at flytte kinesisk opinion i internationalistisk retning. Når det alligevel ikke gik helt galt, må det tilskrives sportens helende virkninger: da OL først var i gang, forstummede de politiske angreb i vidt omfang, redaktørerne hjemme krævede sport, og medierne blev optaget af det, mens kineserne kunne begynde at føle, at deres store indsats blev honoreret. Ingen atleter følte tilstrækkelig stærk lyst til politisk aktivisme og orangefarvede gevandter, og kun nogle få Tibet-nålestik nåede igennem den intensiverede visumkontrol. Det hører med i billedet, at Taiwan-problematikken var bilagt som stridspunkt ved OL; der var mange tiljublede sportsfolk og tre repræsentanter på ministerniveau derfra ved åbningen.

Et andet storpolitisk sigte, reduktionen af Kinas voksende »bløde magt «, lykkedes - i hvert fald for en tid og i dele af verden. ${ }^{23}$ Det afspejles i et Harris-survey i april, hvor 35 \% i EU's store lande så Kina som en større trussel end noget andet land (i 2007: 19 \%, i 2006: 12 \%). Kun spanierne syntes stadig, USA var en større trussel (EUobserver.com 15.4.2008). I en Zogby-poll mente $70 \%$ af amerikanere, at det var forkert at 
give OL til Beijing mod 39 \% året før (Reuters, 2008). Derimod er der ikke så meget, der tyder på et fald i Kinas bløde magt i Afrika, Mellemøsten, Sydasien og Latinamerika. Måske skyldes forskellen et skift i Vestens politik i bredere forstand siden Den Kolde Krig, fra alliance-politik til "gruppe-politik«, hvor der skabes en indgruppe med ønskværdige egenskaber, som minder slående om Vestens egne, og en ud-gruppe af lande med kritisable egenskaber (Deng, 2008, s. 102). At tillægge den anden side en negativ identitet bekræfter og styrker overlegenheden af ind-gruppens identitet. Kinas egen opmærksomhed på blød magt ses af Hu Jintaos udtalelse til "The Hindu " efter OL: "The Olympic spirit will promote the Chinese people to advance their civilization, strengthen the Chinese cultural soft power« (Hindu, 2008).

I alle vurderinger af målopfyldelse må det med, at vi stadig er tæt på begivenhederne; visse virkninger vil først vise sig længere fremme. Den kinesiske mediestyrings påvirkning af meningsdannelsen er utvivlsom, men endnu svær at kortlægge, og der er dokumentationsproblemer omkring udenlandsk aktivitet, som først løses, når arkiverne åbnes i f.eks. Washington.

\section{HVORDAN KONKLUDERE?}

Hvilken lære kan der drages af de modsætningsfyldte resultater: En stærk ekstern dagsordensættelse, men mestendels kun en lille eller ligefrem den modsatte virkning internt $i$ Kina.

Måske var resultat blevet et andet, hvis der havde foreligget større forhåndsviden hos aktører, større indlevelsesevne eller anstrengelser for at sætte sig i »modpartens« sted. Det er måske ikke tilfældigt, at FLG og Greenpeace, og måske HRW-Asia, som alle har udstrakt lokalkendskab, fik de bedste resultater eller i hvert fald ikke blev skadet af forløbet? Det er nødvendigt at indregne de mulige dynamikker, herunder faren for utilsigtede konsekvenser (blowback), før man lægger strategien. IOC kan også pege på resultater, f.eks. på pressefriheden. Rogge havde sådan set ret, da han sagde: "You don't obtain anything in China with a loud voice« (Blitz \& McGregor, 2008).

For det andet er det også vigtigt at forstå, at det kinesiske publikum nu "lytter med" via diasporaen, "netindbyggerne«, studerende og turisme og deltagelse i spirende transnationale bevægelser.

Men for det tredje kommer naturligvis dertil uforudsete elementer $\mathrm{i}$ form af naturkatastrofer (sne og jordskælv) samt virkningen af andre aktørers udspil. Her springer især aktørerne International Campaign for Tibet/Tibetan Youth Congres/Students for a Free Tibet samt RWO i øjnene med deres temmelig dysfunktionelle (og NED-støttede) sololøb. Til gengæld var det nok deres aktiviteter i Lhasa og omkring fakkelstafetten, der fik den største negative blød magt«effekt.

Er der andre ting at lære? Måske, for det fjerde, at medierne er en kompliceret allieret, fordi de er underlagt en række uvedkommende hensyn og i praksis let forfaldt til sensationalisme og upræcis reportage (med undtagelser som James Miles). Endelig må man for det femte være opmærksom på, at der med udgangspunkt i specielt det sino-amerikanske forhold er en stigende mistanke blandt kinesere om, at det i virkeligheden er USA's geopolitiske behov for at stække en "rival«, som ligger bag MR og demokratifremføring. Derfor kan det være en god ide at fremtræde dissocieret fra sådanne eventuelle dagsordener, hvis man vil opnå resultater. For det sjette er ikke noget, der er gratis. Forløbet 
kan måske underminere Kinas forsøg fremover på at øge sin "soft power" (Yang, 2008, s. 248). Men der er omkostninger ved sådanne »beskæringsoperationer «, og de populistiske strømninger i Kina efter årets begivenheder kan fremover blive en alvorlig begrænsning på den kinesiske ledelses ønske om en internationalistisk tilgang i udlandet. ${ }^{24}$ Hvad der sker i disse år, får særlig stor betydning, fordi kineserne er ved at danne et nationalt "selv« i en proces, hvor det dels går hurtigere end ventet frem mod en rolle som stor spiller på grund af den internationale økonomis problemer, dels er lidt foruroligende at se Amerikas faldende rolle, fordi Kina har haft så stor fordel af det USA-ledede system, og endelig på grund af stadig større mangfoldighed og mere differentierede indenlandske grupperinger findes en tiltagende usikkerhed om, hvad den nationale identitet er.

Afsluttende kunne man sige, at selve deltagelsen i OL, fra atleter, politikere, statsoverhoveder og journalister samt det vellykkede forløb, var med til reducere de skadevirkninger, som er kortlagt ovenfor. Her må man sige, at de deltagende idrætsfolk og officials - som længe havde været under et pres, der ikke handlede om sport, men mere om nationale og internationale politiske dagsordener - handlede særdeles modent og ansvarligt i situationen og dermed bidrog til fortsat kinesisk integration og engagement i internationalt samarbejde. Dermed styrkede de også muligheden for fortsatte og stærkt påkrævede fremskridt på menneskerettighedsområdet.

\section{LITTERATUR}

Amnesty International (2006). People's Republic of China: The Olympics countdown - failing to keep the human rights promises. (20. September 2006, Index Number: ASA 17/046/2006) AI Publications.

Amnesty International (2008). Amnesty-bladet, Tema: Den Olympiske Ånd. Maj 2008: Nr. 2., med Årsberetning 2007.

Badger, E. (2008, 7. august). Expecting too much from your host. MillerMcCune.

Blitz \& McGregor (2008, 26. april). Interview with Jacques Rogge. Financial Times.

Buckley, C. (2008, 31.januar). China urged to ratify U.N rights covenant. Reuters.

Carlson, A. (2007). China's Conflicted Olympic Moment. Current History 106(702), s. 252-256.

Chang, Tsankuo (1993). The press and China policy: The illusion of Sino-American relations. 1950-1984, Norwood: Ablex Publishing.

Clausen, S. (2008, 13. maj). Hellig Vrede. Kina - Tibet konflikten: en kommentar. Information, s.3.

CNN (2008). Interview with James Miles. Downloadet 20. marts 2008, fra www.cnn. com/2008/World/asiapcf/03/20/tibet.miles. interview/ 
Cull, N. J. (2008). The Public diplomacy of the Modern Olympic Games and China's Soft Power Strategy. I M. E. Price \& D. Dayan (Red.): Owning the Olympics. Narratives of the New China. Ann Arbor, University of Michigan Press, s.117-144.

Dasgupta, S. (2008, 10. november). Dalai Lama followers responsible for talks breakdown. Times of India.

Deng, Y. (2008). China's struggle for Status. The realignment of international relations. Cambridge: Cambridge University Press.

Eckholm, E. (2008, 11. august). For many expatriates, Olympics signal China's arrival. Washington Post.

Edelman, M.J. (1977). Political language: Words that succeed and policies that fail. New York: Academic Press.

Edney, Kingsley (2008). The 2008 Beijing Olympic torch relay: Chinese and Western narratives. China Aktuell 37(2) s.111-125.

Einhorn, B. \& Delevingne, L. (2008, 22. august). Will the Olympics boost China's Human Rights? Business Week.

Entman, R.M. (1993). Framing: towards clarification of a fractures paradigm. Journal of Communication 41(4), s. 6-27.

Fan, M. (2008, 25. marts). Protesters disrupt lighting of torch in ancient Olympia. Washington Post.
Ford, P. (2008, 27. maj). China enjoys rare moment of international support. Christian Science Monitor.

French, H. (2008, 2. august). Despite Flaws, Rights in China have expanded. New York Times.

French, P. (2008, 22. marts). He may be a God, but he's no politician. New York Times.

Gamson, W.A. \& A. Modigliani (1987). Media discourse and public opinion on nuclear power. A constructionist approach. American Journal of Sociology 95(1), s. 1-37.

Garrison, J. (2005). China's prudent cultivation of "Soft" Power and Implications for US Policy in East Asia. Asian Affairs 32(1), s. 25-30.

Gitlin, T. (1980). The Whole World is Watching. Berkeley: University of California Press.

Goldirova, R. (2008). Europeans think China biggest threat to world security. Downloadet 14.04.2009, fra http://euobserver.com/9/25981.

Herman, E.S. \& Chomsky, N. (1988). Manufacturing Consent. The political Economy of the Mass Media. New York: Pantheon Books.

Jyllandsposten (2008, 13. april). Interview med Søren Espersen.

Kelso, P. (2008, 31. maj). Beijing Athletes urged to speak out on human rights. Guardian.

Lampton, D.M. (2001). Same Bed, Different Dreams. Managing US-China relations 1989-2000. Berkeley: University of California Press. 
Mann, J. (2001). Framing China. I R. Giles, R. Snyder \& L. DeLisle (Red.), Covering China. New Brunswick: Transaction Publishers.

McGregor, R. (2008, 9. april). Olympic protests will inflame nationalism. Financial Times.

Most Americans say China wrong choice for Games: poll. (2008). Reuters 8. april. Downloadet 14.04.2009, fra http://www.reuters.com/ article/sportsNews/idUSN0835446720080408.

Nye, J. (2004). Soft Power and American foreign policy. Political studies Quarterly 119(2), s. 255-270.

O'Connor, R. (2007). The Media Conscience of a Liberal. Downloadet 14.04.2009, fra http://www. huffingtonpost.com/rory-oconnor/the-mediaconscience-of-a_b_68864.html

Olympics - China says it won't submit to pressure. (2008). Reuters 29. januar. Downloadet 14.04.2009, fra http://www.christiantoday. co.uk/article/olympics.china.says.wont.submit. to.pressure/16557.htm.

Pei, M. (2008, 31. august). Were China's glittering Games all gold? Washington Post.

Pew (2000). Self-censorship: How often and why. Pew Research Center for the People \& The Press. 30.april.

Randewijk, M.(2007). IOC disputes Amnesty's campaign on Olympics. de Volkskrant.

14.03.2007. Downloadet 14.04.2009, fra http://en.chinaelections.org/newsinfo. asp?newsid=16373.
Regulations concerning foreign journalists and permanent offices of foreign news agencies. (2008). Downloadet 14.04.2009, fra http://www. shfao.gov.cn/wsb/node111/node125/node128/ userobject1ai1020.html.

Scheufele, D. A. (1999). Framing as a theory of Media Effects. Journal of Communication 49(1), s. 103-122.

Shambaugh, D. (2008, 5. april). China's Competing Nationalisms. International Herald Tribune.

Successful Beijing Olympics boosts China's softpower. (2008). Downloadet 14.04.2009. fra http://www.hindu.com/thehindu/holnus/003200809292031.htm.

Tibet's capital quiet after riots, armed forces remain in sight.(2008). Koydo News International 18. marts. Downloadet 14.04.2008., fra http:// findarticles.com/p/articles/mi_m0WDQ/is_2008_ March_24/ai_n25132605/?tag=content;col1.

Tkacik, John (2008). With repression in Tibet, rethink Olympics. Heritage Foundation. http:// www.heritage.org/RESEARCH/ ASIAANDTHEPACIFIC/wm1858.cfm.

Twelve Suggestions for Dealing with the Tibetan Situation. (2008). Downloadet 14.04.2009, fra http://www.igfm-muenchen.de/ tibet/diir/2008/Open \%20Letter-Chinese \%20 Writers.pdf

Wacker, G. (2008). Beijing is haunted by Olympic ghosts. SWP Comments 9 . 
Wang Yang (2008). China reexamined: the worst offender or a strong contender? Michigan Law Review. April, s. 1143-1155.

$\mathrm{Wu}, \mathrm{T}$. (2008). Are the Media Being too mean to China? Downloadet 14.04.2009, fra http://www. slate.com/id/2197254/entry/2197257/.

Yang, D. (2008). Forced harmony: China's Olympic Rollercoaster. Current History 107(712), s. 243-249.

Zhao, S. (2008). The Olympics and Chinese nationalism. China Security 4(3), s. 48-57.

Østergaard, C.S. (1990). Swans Scolding the tiger? Scandinavian Foreign Policies towards Democratization in China, 1976-1990. Cooperation and Conflict 25, s. 171-194.

Østergaard, C.S. (2008a). China's foreign policy towards US-appointed "rogue states«: interest and principles? Downloadet 14.04.09, fra http://www. asiaportal.info/infocusblog/?cat $=44$.

Østergaard, C.S. (2008b). Kinas Eksperimenter: Reformer og Stormagtsstatus?, 2. udgave Columbus, Kbh.

\section{NOTER}

1. Tre centrale bøger er foreløbig : Karsten Giese, Heike Holbig (ed.): The Beijing Olympics : political, social, and economic implications of a sports mega-event. German Institute of Global and Area Studies. Hamburg GIGA 2008, Xu Guoqi: Olympic dreams : China and sports, 1895-2008. Boston, Mass. Harvard University Press 2008 Price Monroe E. \& Daniel Dayan(ed): Owning the Olympics : narratives of the new China Ann Arbor, Mich. University of Michigan Press 2008.

2. Det hører med til baggrunden, at de første offentlige ønsker om, at Kina skulle være vært for OL, kom i 1908, at især USA i 1993 forpurrede, at 2000-legene gik til Beijing, samt at landet uden problemer afholdt de store Asian Games for 37 lande i 1990, og Universiaden i 2001, det år hvor man omsider fik tildelt værtskabet.

3. Den amerikanske Kongres« Congressional-Executive Commission on China afholdt 27.februar en høring om "The impact of the 2008 Olympic Games on Human Rights and the rule of Law in China«. Panelet (dvs vidnerne) ved høringen bestod udover en miljø-embedsmand $i$ al sin alsidighed af tre ledende medlemmer af menneskerettigheds-NGOer med interesser i Kina. Der blev aldrig udtrykt bekymring over valget af Seoul i 1988, trods Syd-Koreas alvorlige menneskerettighedsproblemer: standarderne synes at være forskellige for allierede og ikke-allierede.

4. Allerede i april drøftede "World Sports Law Report « de forskellige indvendinger mod boykot i artiklen "Ten reasons against boykoting the Beijing Olympics"

5. James Mann, fra Los Angeles Times, er en nestor blandt Kina-korrespondenter og har skrevet flere vigtige bøger om USA/Kina forholdet.

6. En endnu hårdere linje formuleres af Herman og Chomsky 1988, under betegnelsen " A propaganda model«.

7. De komplicerede forhold omkring Tibet er overskueligt forklaret i Melvyn Goldstein: The Snow Lion and the Dragon. China, Tibet, and the Dalai Lama, Boulder, Westview Press 1999, og på dansk i Østergaard (2008a)

8. F.eks. påstandene om kinesisk folkemord på 1,2 mio. tibetanere.

9. Da faklen påbegyndte sin tur i Kina og skulle tændes på Tiananmen, lykkedes det et nyhedsbureau at få kritik af OL ind i hvert eneste afsnit af sin reportage fra ceremonien.

10. Eksemplet berører en anden NGO, som fik megen mediebevågenhed før og under OL, nemlig Centre on Housing Rights and Evictions, COHRE, som anførte, at ikke mindre end 1,25 mio. mennesker var tvangsflyttet før Legene. Den eneste måde, man kan nå op på dette tal, er ved at medtage alle moderniseringer, saneringer og byrenovatio- 
ner i samtlige OL-byer siden 2001, hvor Kina fik legene, det vil sige f.eks. overalt, hvor en skyskraber har erstattet enetageshuse. Der er 4000 skyskrabere i Shanghai. Beijing bys mere præcise tal for, hvem der er eksproprieret pga olympisk byggeri er 14.901 mennesker i 6.307 husstande (BBC news 20.2 2008). Der er naturligvis en ekspropriationslovgivning, og kompensationerne er i international sammenligning fuldt acceptable.

11. Personlig oplysning fra Bill Schiller, Asia Bureau Chief for Toronto Star, som mødtes med de to, da myndighederne i øvrigt 14 dage senere ophævede varetægtsfængslingen.

12. En af de mest erfarne EU-korrespondenter i Kina formulerede det sådan for mig i marts 2008: „Can we list Beijing as the first time we see the occurrence of the "deadly alliance» of media and non-governmental organisations in the Games?"

13. Proxy-servere og umuligheden af at censurere f.eks. email er ved at ændre mediebilledet, se også Kirsty Needham: Mice starting to win in the Beijing blogosphere, Sydney Morning Herald 25.11 2008. Artiklen peger på de omkring 100 millioner kinesiske blogs.

14. Problemet skærpedes af, at redaktionerne pressede medarbejdere med kun anekdotisk viden om Kina til at udfylde "rammen«. På Information måtte koryfæer som Lasse Ellegaard og Georg Metz levere helsider om OL, som til alt held næppe blev set af menige kinesere.

15. Omsorgsfulde personer fandt også, at omkostningerne var urimelige for et uland. Men Kinas valutatab ved f.eks. USA's rentenedskæring i januar 2008 kostede landet mere end dobbelt så meget som hele OL, og de fleste penge gik jo til infrstrukturinvesteringer, som alligevel skulle være foretaget: 9,5 $\mathrm{km}^{2}$ byudvikling, 6 nye undergrundsruter, en ny lufthavn, $40 \mathrm{~km}$ letbane samt sportsarenaerne. »Brand«-gevinsten og TV-indtægterne var enorme.

16. En leder i Folkets Dagblad skrev allerede i starten af året om aktivister, der bruger OL til at presse Kina: "There is no country in the world hosting an Olympics, which would compromise on its own core interests« (Reuters 29. januar)

17. Til de politiske mål skulle måske tilføjes miljø og klima. På trods af (eller på grund af?) store forudgående bekymringer, viste miljøbeskyttelsen ved »Green Olympics « sig at fungere. Selv grundvandet under Beijing begyndte for første gang i årtier at stige, og himlen var blå. Se f.eks. R.W.Mead and V.Brajer: Environmental Cleanup and Health Gains from Beijing's Green Olympics, China Quarterly 194, 2008 pp.275-293.

18. Der er også forskere, der opfatter de to nationalismer som én: "Kinas nationalisme er både bygget af en stolthed over den kinesiske civilisation såvel som på følelsen af at være blevet ydmyget i mere end et århundrede af Vesten og Japan « Li Xing : "Vestens Kina-syndrom», Kritisk Debat, Oktober 2008.
19. En tidlig bevidsthed om dette ses i Gudrun Wacker: »Beij ing is haunted by Olympic ghosts «, SWP Comments nr. 9, Stiftung Wissenschaft und Politik, Berlin.

20. På en enkelt dag i april var der f.eks. 2 mio. kinesere, som indsatte "Jeg [hjerte] Kina" som SMS-signatur. Og $80 \%$ der i et survey mente, at vestlige nyhedsmedier gav et biased billede af Kina. I øvrigt var $74 \%$ »excited or very excited« over værtsskabet iflg. et survey af mediefirmaet Millward Brown. Halvdelen af de 1.3 milliarder så åb ningsceremonien på TV. En tredjedel af verdens befolkning så den.

21. Samtale, maj 2008.

22. En anden sammenlignede med negrene i Sydstaterne under racediskriminationen: "there is a sense that no matter what China does, it won't really be accepted as an equal on the world stage, that it will always be left cleaning the toilet at the OECD country club « (Tim Wu 2008).

23. Defineret som evnen til at påvirke, hvad andre ønsker og hvordan de skaffer sig det, især ved at fremhæve vigtigheden af et lands system, kultur, værdier i frembringelsen af de ønskede goder eller den ønskede tilstand.

24. Se f.eks. F.van der Putten: China and the danger of antiWestern boykots. Netherlands Institute of International Relations. Clingendael 2008 